Vantage: Journal of Thematic Analysis

ISSN: 2582-7391

A Multidisciplinary Publication of Centre for Research,

Maitreyi College, University of Delhi

October 2020, Volume 1, Issue 2

Original Research Article

\title{
Living on the Margins: An interpretative study of Sanitation Workers amidst COVID-19
}

Anmol Chugh, Anjali Bisht, Nikita Sarma, Subhangki Koushik, Pawan Harsana* \& Sana Khan

Department of Sociology, Maitreyi College, University of Delhi

*Correspondence: pharsana@maitreyi.du.ac.in

\begin{abstract}
This paper deals with the inhuman ordeal of sanitation workers amidst the COVID-19 pandemic. It begins with the assessment of historical conditions such as the caste system, responsible for the marginalization and grave humiliation of manual scavengers in contemporary India. It is difficult for them to break away from their jobs because of the caste system which traditionally dictates the person's occupation. As a result, the ongoing COVID19 pandemic has further disenfranchised their state, forcing them to work at the forefront, clearing toxic waste without basic protective gear. This inclines towards the dangerous effects on the health of the sanitation workers and the urgent need to highlight their plight in the mainstream media. The paper also discusses labour laws and political measures of upliftment to understand the constitutional provisions. Certainly, the ideals of equality and justice do not stand closer to truth in the face of the miserable condition of manual scavengers amidst COVID19.
\end{abstract}

Keywords: Manual scavenging, Media, health, COVID-19, Marginalization.

\section{INTRODUCTION}

Manual scavenging is an age-old practice, not much talked about yet prominently existent in the Indian context. Even during the difficult times of COVID-19, manual scavenging continues as before. When life has altered globally due to the pandemic, and people from all walks of life have experienced a change in the way they work, with 
the movements and activities of people being contained and restricted due to the pandemic, the manual scavenging continues, as it was before the pandemic.

This, despite its continuity in the crisis, remains very less talked about. Manual scavenging has never gained focus, socially and otherwise. It does not make the headlines nor does it affect civil society. Scavenging, though important for the society, in terms of hygiene, does not figure in our discussions of social issues. This paper seeks to bring forth the plight of manual scavengers in the time of the pandemic.

This study focuses on the marginalized state of the manual scavengers and how COVID-19 has led to further reinstate their marginalized status. Manual scavenging is a continuing practice that persists in India despite the prohibition of employment of manual scavengers. Although there are legislations and policies to support and rehabilitate them, there is a lack of implementation of these regulations. The term 'manual scavengers' itself is vague as there exist about nine categories of scavenging work in India. In this study, we try to focus on the 'sewer cleaners' category of manual scavengers in India. The procedure of unblocking, cleaning, and wastewater drains is a part of sewer immaculation which mostly takes place in urban areas. Finally, several ways to combat their plight during the pandemic are suggested so as to reform and improve the current, miserable state of the sewer cleaners.

\section{METHODOLOGY}

The research looks into the plight of manual scavengers through a sociological perspective. The use of interpretative sociology for the same attempts to understand social phenomena from the standpoint of those involved in it. By this method, researchers work to understand how the groups they study as 'subject' construct the reality of everyday lives through the meaning they give to themselves.

On the other hand, sociological imagination is centered on examining our relationship between biography and history. It provides room to stand apart mentally from our limited visuals or experience and help us trace a link between private concerns and social issues (Mills, 2000). Through this paper, we seek to understand the human condition of manual scavengers by trying to construct the meaning of their actions and outcomes with an empathetic outlook.

Vantage: Journal of Thematic Analysis, 2020; 1(2): 127-153 
The primary source of research is based on secondary data accessible from various sources in the form of sociological articles, journals, and past research papers. Also, the historical method of social research is used to comprehend various intersectional areas of inequality continuing for a long time.

The study brings forth to locate the factors that are prominent in the operation of a system of graded inequality. It aims at better policymaking, better governance, and a life of dignity for the marginal section, wherein lies its sociological relevance.

\section{DISCUSSION}

\subsection{Shadow of Caste}

"In India, a man is not a scavenger because of his work. He is a scavenger because of his birth irrespective of the question of whether he does scavenging or not.” - B.R. Ambedkar (Kumar \& Srivastava, 2018)

Faces covered with filtered masks, foreheads wrinkled due to the stinky smells of the gutter, people pass by manholes in the streets, more worried and irritated with the black water of the gutter that could possibly spoil their expensive shoes. Little do they realize that as a society they have spoiled the fates of many (manual scavengers) by burying them deeper and deeper in those manholes.

It is a picture of one of the most abominable realities that exist in every part of India where there is a lack of proper and efficient sewage systems or safe fecal sludge management practices. For a country that is seven decades into its independence, it is a tragedy that a section of its population still earns its living on the margins. The COVID19 pandemic has further created an inhabitable situation for manual scavengers in the country. Along with their regular task which incorporates sewer cleaning and waste management, they now have to go for fogging and spraying of disinfectant in containment zones. Sundharam of Senkodi Sangam, a union of sanitization workers working for Greater Chennai Corporation in an interview said, "Our workload and working hours have increased during the lockdown. Though the government had made many promises about our safety and wages, nothing has been done so far" (News Click Report, 2020). Centre of Indian Trade Unions (CITU) affirmed that even during the 
pandemic, the sanitation workers are being constrained to enter manholes and demanded that this be stopped immediately. Since it is contractual work, the government has not considered paying proper attention to the interests of manual scavengers. The workers, unions, and activists have long been demanding the end of the contractual practice. Their struggle to safeguard the interests of the manual scavengers has suffered greater damages amidst COVID-19. Before the Pandemic, the central government recognized the presence of 54,130 manual scavengers until July 2019. During the pandemic, the number of employed manual scavengers is not clear but further worsening of their state is quite evident as per the few scattered reports and case studies recording their plight. The aforementioned case studies, reports, and articles have received premiere attention throughout our research. The utmost violation of their rights at this time is reflected in their forced deployment in high-risk areas without protective measures. As reported, around 6500 workers in Mumbai were deprived of any kind of protective equipment. Various guidelines and rules were issued by the government on the use of PPE and handling of waste of COVID-19 patients but due to lack of proper enforcement, manual scavengers continue to suffer endlessly (Gautam, 2020).

The practice of manual scavenging is a caste-based and hereditary occupation reserved exclusively for the people of so-called lower castes. It has been a persistent practice in India, home to a centuries-old caste system where communities are confined to certain jobs based on the family they are born into. The occupation of manual scavenging portrays a prominent form of caste discrimination and inhuman practice of untouchability that continues to thrive in India.

The caste system is an age-old tradition in India that socially stratifies people into different categories termed as 'Jati'. Certain occupations are ascribed to certain castes by birth. It is a system that divides people into four Varnas maintaining a hierarchy. The fifth category of people, known as the 'untouchables' occupy the lowest position in the hierarchy and are considered to be polluting. The notion of purity and pollution cannot be interpreted scientifically in terms of cleanliness, hygiene, and health, though ironically it is also not uncommon to find educated people trying to support their ideas using scientific explanations. This has created a cesspool of problems and further 
marginalized the manual scavengers working at the forefront during the pandemic. The prevention of the spread of this virus is associated with one's cleanliness but the sanitation workers are deprived of it due to their work and habitual circumstances. Their caste identity has pushed them to accept their occupation as god-given and being devoid of necessities amidst the COVID-19 pandemic. The caste system was introduced to celebrate the differences between various castes and to bring order in the society though it ended up dividing the society into upper and lower strata, further leading to discrimination and inequality of resources (Hindustan Times, 2003). Ambedkar (1979) calling the caste system a system of 'graded inequality' with castes considered high or low based on relative degrees of ritual purity or pollution and of social status stands evident to the above analysis (Thorat, 2017).

Both Gandhi and Ambedkar dealt with the issues of caste in India. They saw the problems of untouchability but their approach to combat was very different. For Gandhi, caste was a functioning system that involved the division of labor. He wished to eradicate untouchability but maintained the Varna system. On the other hand, Ambedkar pointed out that it was actually a division of laborers involving gradation by birth, hence demanded annihilation of caste. Where Gandhi foresaw an upliftment Ambedkar foresaw an upsurge (Ambedkar, 2014).

In his voluminous writings, Gandhi contacted or stayed upon myriad issues of interpersonal, intergroup, and individual-group relations that influenced society and called for change and even progressive change in the structure, establishments, and processes and value orientations of society. Despite the fact that his viewpoint was Universalist in nature, his place of the flight was the contemporary Indian Circumstance (Anand \& Vellanki, 2015; Rinker, 2017).

The focal element of Gandhi's idea is that it is a man focused, not framework focused. Its premise is the moral autonomy of man and the chance of his enduring freedom from his own lower self within the structure of the society. The ideal social order is what offers man the chance to understand his ethical independence and encourages him to practice this self-governance in an edified way that is helpful for individual and collective well-being (ibid.). 
On other hand, Ambedkar writes: "A caste has no feeling that is affiliated to other castes, except when there is a Hindu-Muslim riot. On all other occasions each caste endeavors to segregate itself and to distinguish itself from others" (Anand \& Vellanki, 2015). Living in such a state of exception for low-castes involves a consistent process of drawing limits between their identity and that of others both higher and lower in rank status. In such a context, the telling of stories can be understood as oblique or "hidden transcripts" (Couillard, 1990) that challenge any lack of awareness of the low-caste social predicament.

It is argued that the pervasive and elusive reality of structural violence in the lives of anti-caste activists is what mobilizes an identity for change and builds an awareness of rights. In critically analyzing what Volkan (1997) calls the "chosen traumas" and "chosen glories" of the anti-caste movement we can read the narratives of Dalit activists at strategic opportunities for social and structural change of systems of violence. Though Dr. Ambedkar may not have talked about the realities of caste in the language of structural violence, he understood that what we now call structural violence represents the foundational context to challenge in creating social change (ibid.).

Ambedkar's critique of an Indian nation was molded by his own insight of caste and empowered by an anti-caste reading of pre-modern Indian history. Without such a complicated and multi-layered critical history, Ambedkar's importance to many anticaste activists is undermined and the opportunity space for any narrative shift on caste is limited. The task of activists embedded in the ongoing dynamics of caste contention is to endeavor to understand the narratives of the marginalized as teeming with "hidden transcripts" (Couillard, 1990) ripe for intervention towards social change.

Ambedkar's ideas and narratives of low caste identities helped people to see the ugly face of the caste system but the annihilation of caste still is a dream in India (Ambedkar, 2014). Here is the story of Rajan, a sanitation worker. He works in the "Second Best" realty city of India, goes down the sewer every day with nothing but a rod and a handkerchief on his face. The foul smell emerges from the deep sewer and soon his whole body is covered in the black fluid which is the toilet waste of the nearby housing societies. Not only is this dark, cramped hole into which Rajan steps, hazardous, it is 
also illegal; especially without protective gear. However, with a smile on his face, he says, "This is all I know and I have a big family to feed" (Majumdar, 2020). "They gave us some pairs of gloves and a few masks but they were torn after just a day. We asked for more gloves but they said it is going to take time”, he says (Ibid). When they demanded hand soap, the contractor gave them cheap soap. When the workers asked for Dettol soap, the contractor refused and said, "what will you guys do with Dettol?" (ibid). Despite this callousness, it is the workers who pay for the contractor's negligence. For the people from the Dalit community, social acceptance is still a luxury. In a country where Dalits are beaten up for riding a horse on their extensively addressing this issue wedding, people like Rajan know that they will continue to suffer under this system.

The ongoing global struggle against COVID-19 also colors itself in the glaring light of the caste hierarchy. In a recent report by The New Indian Express, seven sanitation workers had tested positive for COVID-19 in Vijayawada early in June. All of them who were below 50 years of age contracted the virus while at work. On May 24, a 58year-old sanitation supervisor at All India Institute of Medical Sciences (AIIMS) in New Delhi had died ofCOVID-19. Apart from this, about 50 sanitation workers from AIIMS have tested positive (The New Indian Express, 2020).

Their struggle takes a backseat because their caste identity is labeled down on the hierarchical ladder. Their identity would have been used, reused, and misused profusely if the pandemic served as a battleground for electoral caste politics. The shadow of this system haunts millions and millions in this country during this difficult time. Their struggle needs recognition but more than that their struggle needs to end. A transformation needs to start urgently not only for sanitation workers but for every Dalit in every sector of this country.

Even after years of struggle including several cultural movements, political promises, and mass mobilization, caste as a ground for unequal treatment ceases to disappear even in contemporary India. Caste's favoritism and social exclusion of Dalits have infused every private enterprise even in the most dynamic modern sector of the Indian economy (Thorat and Attewell, 2007). Unless the mindset of people undergoes a drastic change, 
the tentacles of caste will continue to influence all our lives (Gnana, 2018). Its imprints are so deep in the Indian subcontinent that every issue whether it is social, cultural, political, or economic it has a caste dimension to it. The COVID-19 pandemic is further proving to be an apocalyptic state for manual scavengers.

\subsection{Practical Landscape}

The apocalypse has submerged the lives of the manual scavengers in the whirlpool of humiliation, oppression, and injustice highlighting the linkage between the "personal troubles of milieu" and the "public issues of social structure" (Mills, 2000). Manual scavengers are experiencing a crisis wherein their values are threatened; yet, they stand still without a voice, and silenced by silences. In Coimbatore, millions of rupees are generated by unlicensed contractors from the wages of sanitation workers by cutting their salaries (Thomas, 2020). The standardized wages under the Minimum Wages Act of 1948 were never paid to the contract labourers. Even though the Contract Work Abolition and Regulation Act (1970) banned the appointment of contractual workers, there are still many workers who have been working for more than a decade. The ground reality and the prescribed laws do not coincide with each other. The risk of infection for sanitation workers has been increased by Covid- 19 as highlighted by OAR research. The lack of awareness about the Covid-19 infection makes the situation of workers even more vulnerable.

According to the latest findings by The Swaddle, in the peripheral region of Delhi, hazardous gases from the sewage while cleaning became the reason for the death of a worker. This worker was working to limit the spread of Covid - 19 (Torgalkar, 2020). These kinds of difficulties come to pass due to historical settings. It is important to analyze them as C. Wright Mills remarked "neither the life of an individual nor the history of a society can be understood without understanding both" (Mills, 2000). Practically, all the sanitation workers who manage human excreta are from certain Dalit castes and communities. Safai Karamchari Andolan has recorded nearly 2000 sanitation worker deaths, yet experts believe that genuine figures could be much higher if a total check was conceivable (Desai, 2020).

Vantage: Journal of Thematic Analysis, 2020; 1(2): 127-153 
In the National Safai karamchari Aayog's (NSKA) pilot study, six of Karnataka's 30 districts have discovered 1,720 manual scavengers. In a testimony submitted to the Supreme Court in 2018, the Government's administration denied this claim (The Hindu, 2020). This declaration of Government is questionable. Unmistakably, the legislature was being insincere in introducing the genuine picture under the watchful eye of the apex court. The NSKA figures relate to only six districts. The state-wide figures for the manual scavenging are likely to be multiple times bigger.

In the broader context, it is evaluated that five million people in India are occupied with sanitation work (that is, work identifying with the cleaning and the executives of toilets and human excreta), of which two million are likely to be occupied with 'high-risk' work, such as, cleaning sewers and septic tanks. Moreover, a lot of the sanitation work is acted in debasing and disparaging conditions, and for low wages and in uncertain working conditions. It mirrors the fragmented and incomplete understanding of the policy and strategy side of what the sanitation challenge comprises. Crucially, workers (and the families of sanitation workers) stay caught in conditions in which they need to continue performing dangerous and humiliating sanitation work, regardless of the heavy price they need to pay for it. This is India's foremost sanitation challenge; extensively addressing this issue ought to be the foundation of India's next sanitation strategy.

In the Parliament of India, the Union Ministry of Social Justice disclosed that from 2016 to 2019, during the cleaning process of sewers and sewage tanks, 282 workers lost their lives (Desai, 2020). With statistics of death mounting to this height even before the pandemic, a is needed is a quality of mind that will help to use correct information and to develop a reason to achieve lucid summations of what is ongoing and what can be the possible solution. In other words, a sociological imagination to grasp history and biography and the relations between the two within society is crucial (Mills, 2000).

Employment of manual scavengers and building of dry latrines are forbidden as per the laws binding the Indian state (Singh and Unnikrishnan, 2020). It is actually a punishable offence. But the persistence of these practices on a continuous basis, bores testimony 
to the dehumanizing condition of manual scavengers in our country and also to the nemesis of humanity within human beings. The underlying causes are found to be poverty, unemployment, the caste system, and insensitive society. Poverty is more prevalent in rural areas of India, mainly higher among the SCs and STs on the whole and other minority groups. According to the Consumption Expenditure Survey, 61st round, 2004-05 "the highest poverty rates are seen either for the SCs or the STs across all religions, accounting for highest 50\% for STs and 37\% for SCs amongst Hindus" (Thorat, 2010). This implies that people from lower strata of society mostly end up with jobs that are not well paid and are hazardous like manual scavenging.

\subsection{Political Reality}

"There is no political will to implement a law against engaging humans to manually clean drains" - Bezwada Wilson (Dey, 2017).

As stated by the official government statistics, since the beginning of 2017, every five days at least one worker has died in India while cleaning sewers and septic tanks (Nair, 2018). Since the 1950s, the main goal of the Indian government has been to tackle this issue but the National Commission of Safai Karamcharis (NCSK) opposed by saying that the actual rate of the death toll is higher than the available data around 776 workers lost their lives. Manual Scavenging is strongly rooted in the caste system and therefore has continued to exist even after India became modernized (Dash, 2019).

The Central Government passed the Prohibition of Employment as Manual Scavengers and their Rehabilitation Act in 2013 making it mandatory for all the states to follow the proposed guidelines. The only difference that makes it stand apart from the 1993 law, is its inclusion of manual cleaning of sewers and sewage tanks within its fold. This was indeed a giant leap in ensuring the safety of sewer cleaning workers who face higher risks of losing their lives. However, the steps taken by the government under the Swachh Bharat Mission(SBM) and AMRUT have only led to an increase in the death of manual cleaning workers. When asked about this and the persistence of the practice of manual scavenging to the government in Lok Sabha, Minister Shri Ramdas Athawale replied to it by asserting that the government has taken various initiatives to tackle the issue ("Questions: Lok Sabha", 2020).

Vantage: Journal of Thematic Analysis, 2020; 1(2): 127-153 
Section 2(1) (d) of the Act characterizes dangerous cleaning as "the manual cleaning of a sewer or a septic tank without defensive apparatus, cleaning hardware and observance of safety precautions"(The Gazette of India Report, Ministry of Law and Justice,2013). Violation of security safety measures is viewed as a criminal offense. The Act expresses that, in specific situations, manual cleaning is permitted under uncommon and exceptional cases, given defensive rigging and wellbeing gadgets. For this, consent is required from the $\mathrm{CEO}$ of the nearby authority in the wake of expressing the explanation behind permitting such cleaning in the written form. Hence, limitations are not appropriate when manual cleaning is finished with the utilization of all the wellbeing gear referenced in the Act itself (Singh, 2017).

Despite the act prohibiting any individual from being employed to clean sewers or septic tanks without equipment, it does not give any alternatives for the same. In a survey that started the Central government in 2018 in 84 districts of 14 states, it was brought to light that there were more than 40,000 manual scavengers in these places. This number was thrice the one in 2013 ( Mishra, 2019). The Indian Government devised the rules for this law specifying the compulsory usage of mechanical equipment in addition to regulations for any emergency demanding human involvement in cleaning. However, there is no clarity as to what would account for such an emergency (Singh, 2017).

As per the standpoint of Human rights activists, contractors utilize this obscurity and appoint workers to clean dangerous sewers and septic tanks. This is more cost-efficient for them than making use of machines but is life-threatening for the workers. The work is portrayed as fully automated on paper but in reality, things differ. Workers are not aware of the availability of protective equipment. A quite number of manual scavengers work between 8-10 hours a day and many are forced to work when not in better health (Prasad, 2005). They accept that occupation because they think they are ought to. Being less informed about what the law says, they enter into the deadliest space to earn a living. Bezwada Wilson says, "While equipment like jetting and suction machines and safety gear for sanitation workers in case of emergency remain mandatory on paper, they fail to materialize on the ground" (ibid.). On the ground, the cleaning is done with manual intervention as most contractors do not have the necessary machines to provide. 
The poor men also cannot reject the job offered to them, as they see some extra cash coming. New Delhi reported the death of 10 sanitation workers over July and August 2019 where the workers were found cleaning sewer without protective equipment.

Making the work contractual contributes towards worsening the living conditions of such workers. In India, municipal corporations across various states use the contract system to hire sanitation workers. Even though upper caste groups may be hired for some sanitation work, they further contractualise the work by hiring Dalits on fewer wages and pay a little amount to the officers as commission for turning a blind eye (India Spend, 2017). It is quite noticeable that in every corner of India, the task of manual scavenging is mostly done by the Dalits. No other caste is willing to do this work and this task is automatically associated with certain castes as their traditional occupations. The persistent practice of manual scavenging in India despite laws against it is evident in the great grip of caste atrocities and practices in India.

A real-life account of a manual scavenger in Chennai named Y. Manikandan showed how he is appointed for Rs. 360 a day for cleaning sewers. The working process is extremely hazardous where he has to enter a manhole without any sort of protective gear and clear out the clog in the drains using his bare hands and a metal rod. Amidst this, he has to come up to take a breath so that he isn't choked by the poisonous hydrogen sulphide and carbon monoxide from the waste. Manikandan's wife, Muniammal is in constant worry and fear for her husband's life as he does this lifethreatening task every day without any security. She isn't sure if her husband will return home safely from work. Manikandan is exposed to the aftermath as he often has rashes on his body and has even neared losing consciousness due to the toxic fumes. The shadow of this humiliating work continues to lurk him as he loses his appetite due to the stink of excreta that doesn't leave his body (Gandhi, 2018).

Furthermore performing the most humiliating task, they continue to live a life of poverty and humiliation faced at the hands of society. The wages they earn are not enough to sustain them. They have no job security due to the looseness of contractbased employment. The jobs they perform align them with a social stigma and deem them to face discrimination and the staunch practice of untouchability. 
In New Delhi for mere payment of Rs 7500 to 10,000 per month, Joney, Brijesh, and Mange, are sewer cleaners entering gutters to clean out stench and filth daily. They belong to the Valmiki community, considered to be one of the lowest in the Dalit community. They have acquired this occupation of sanitation and cleaning as part of a tradition. They enter sewers half-naked without any safety masks or equipment. To prevent them from suffocating from the hazardous gases in the gutters, they are tied to a safety belt which can be pulled to gasp a breath. Their supervisor, Mr. Ratender Chauhan reported that most sewer cleaners suffer from eye problems, respiratory diseases, and skin diseases (Agencia EFE, 2018).

Under the National law, India has constitutional provisions out of which most important is the abolition of Caste discrimination (Article 15) and Untouchability (Article 17). More importantly, Article 21 of the Indian Constitution lays out that "No person shall be deprived of his life or personal liberty except according to a procedure established by law" (Ambedkar, 2018).It guarantees everyone a life of dignity free from exploitation. However, these three articles and their recognition remains a theoretical concept in India. Despite laws and provisions, the nation hasn't been able to establish an equitable casteless society. India is obligated to banish the use of forced compulsory labour under the Forced Labour Convention of 1930. It was amongst the first few countries to ratify to the ILO Convention 111. The convention strives to promote equality in our employment and occupation by eradicating any form of discrimination especially due to social origin. This is the greatest irony for India where the entire system of employment, especially sanitation work and cleaning is rooted in caste which is inherited by birth (Preet \& Chaturvedi, 2019).

\subsection{Mainstream Alienation}

The Coronavirus pandemic has impacted the human race to such an extent that it changed the way the world and everyday life was perceived earlier. With the majority of the public staying home because of nationwide lockdown to aid stop the spread of the virus, people have few options in hand but to rely even more profoundly on media and technology to keep updated and stay connected. With COVID-19 here to stay, people need access to different types of media to gather all the information they need 
to stay informed, safe, and connected. However, there exists a massive digital divide in the country which confines the access of digital media to certain sections of the society.

Media can truly act as a harbinger of hope and comfort by making itself accessible to all sections of society and by unfurling awareness drives. Media is a tool that can act as a link between the people and the government. Issues related to human rights violations should be prioritized in print media to reach out to the masses and to draw public interest. A report on comparative analysis between two leading newspapers of India, The Hindu and The Times of India shows how much space they give to issues concerning human rights in respective papers. It reveals that the issue of manual scavenging gets zero centimeters per square space in comparison to issues such as state-sponsored violence, suicide, molestation/ sexual harassment, violence, murder, and rape (Sahu and Ahmad, 2018). The voices of this category of people are unheard even though their jobs prove to be the deadliest and most inhuman.

An eye-opening instance is that, at 5 pm on Sunday, 22 March 2020, following the plea of our government, people all over the country applauded to pay a tribute to the health care professionals working on the frontline, but there was no acknowledgment for the contribution of manual scavengers who are equally working on the frontline. The manual scavengers handle and clean medical waste without any protective gear.This brings forward how critical stakeholders engaged in sanitation work continue to face numerous challenges around safety, health, dignity, and rehabilitation.

India has numerous legislations and laws banning the profession and employment of manual scavengers, however, that has not made much of a difference. Manual scavenging is still practiced by large numbers to sustain themselves in the face of acute poverty. Moreover, they face extreme humiliation, and untouchability is practiced towards them. Reports showing the ground reality should be brought to the fore to help the society understand the barbarism of manual scavenging. Since 2000, the Safai Karamchari Andolan has started recording nationwide figures of deaths of manual scavengers; it has fastened the death count at 1,760 in recent years as reported (Desai, 2020). The soaring numbers are a testament to the repressive condition of manual scavengers in the country. Hence, to bring change in the country, the marginalized 
people need to be uplifted by recognizing their voice and by highlighting their plight in the mainstream media with proper analysis and interpretation.

There also exist very few examples of print media wherein the accounts of manual scavengers have been recorded. For instance, in 2017, Joopake Shubhadu wrote about her experience as a manual scavenger to the Telangana government. She talked about facing discrimination from her own family as she wasn't allowed to touch anything in her house for several days (Kannan, 2019). Manual scavenging jobs are extremely demeaning and humiliating but the stereotype involved around these jobs is even greater and evident in society. Other forms of print media such as literature highlight the life and oppression faced by Manual Scavengers. The book "Unseen: The truth about India's Manual Scavengers" by Bhasha Singh (2014) which showcased the immense exclusion and disgrace experienced by manual scavengers in their daily lives. Novels like Thotti (1948) by Thottiyude Makan was an account of how the community of scavengers struggled to free themselves from the typecast image of their jobs. Accordingly, there is enough evidence of the stereotype around people practicing manual scavenging. It is instilled in the minds of people. Although print media has a meaningful impact it cannot be ignored that it has a very limited impact. The reach of print media is restricted to an interested audience and literate sections of the society. Moreover, many times the way sanitation workers are captured in the news particularly to focus on death tolls reducing them to mere statistics. Their issues and demands hold no importance in mainstream media (Kannan, 2019).

Again, there is no featured film that has been made which revolves around the lives of manual scavengers in mainstream and visual media involving movies and films. There is barely any representation. We often see debates over several issues on various news channels but the lack of coverage given to the issue of manual scavenging articulates the biased role of media in informing people and spreading awareness about the anguished. This holds even in the realm of social media wherein a lot of misinformation has been circulated by established news agencies only to increase their TRPs. The issues concerning the manual scavengers never receive acknowledgement because half of the population who directly or indirectly function in the oppressor category cannot relate to that kind of content and want to focus the least on such issues. Their disinterest 
has created an arc of alienation in the mainstream media regarding the issues of manual scavengers. This attitude has also influenced the historical telling of events where the interests and conditions of manual scavengers were limited to the periphery of academic research. The significance of the media doesn't end with highlighting the plight of sanitation workers and printing reports. They also need to act as a medium to focus on occupational immobility and lack of access to education that Dalits face. Education can help them shift their occupation and give them a chance to better their livelihood. The mainstream media can bring the needy ones to the forefront, however, the foundations of the caste system restrict it. Only in recent years, a shift in paradigm has been witnessed to focus on the enfranchisement of underprivileged groups in academia.

Discussions and reports on manual scavenging by print and visual media cater to different audiences. Their plight can only be highlighted and uplifted through an honest portrayal of their struggle. The current Indian media- scape has become a battleground of elitist ideologies. Their prime responsibility to speak for the unheard and develop public consciousness around issues dealing with the oppressed has been reduced to mundane, repetitive upper caste, class discourses which do not showcase the India that needs a platform to voice out its concern. Many of the alternate counter-voices have raised genuine issues of social concern during the pandemic outbreak. But the already oppressed manual scavengers remain unrecognized and shunned amidst the COVID-19 pandemic.

\subsection{Health}

Manual scavengers face life-threatening risks at each stage. This can be highlighted more clearly by analyzing health-related issues with this practice. Using just a stick brush and a little tin plate, they clear excrement from open and private restrooms onto crates or different containers, which they then carry on their heads to dumping grounds and disposal sites. A majority of municipalities in Indian are not well equipped with the required machines to clean sewers. The sewer worker is responsible for assessing and maintaining the sewage structure which comprises underground pipes. They are required to empty out solid waste that blocks the flow. 
Manual Scavengers around the country are not only crippled by the social norms but are also exposed to unsafe working conditions which results in various health complications. Prolonged exposure to hazardous gases in their occupation often becomes the reason for their untimely demise (The Hindu,2020). It is not uncommon in India for all kinds of sanitation workers to work without personal protective equipment. Most of them operate with little to no formal training on the occupational risks of their work. The existing protective equipment is neither adequate nor up to the standard quality. Multiple factors cause poor occupational health and safety issues which need to be addressed systematically. Receiving vaccines and regular health checkups and having health insurance is also not widely accessible for the workers.

Where sanitation workers are predominantly from lower-income segments of society, their occupational hazards tend to be compounded by living in overcrowded slums, with poor water and sanitation, and, many times, in flood-prone environments. These conditions increase the environmental health risks. Also, many of them are not educated to use protective equipment and the importance of it. Most of the wage workers are recruited on a contract basis and daily wages.

In a study by TISS, $80 \%$ of the workers die before age 60 because of work-related health problems. In Mumbai, an average of 20 sewer workers die each month from accidents, suffocation, or exposure to toxic gases, the study found (Parth, 2014).

The Supreme Court considers the Right to Health as one of the fundamental rights under Article 21, Right to Life. The Supreme Court initially considered Right to Health as a part of Directive Principles of state policy and declared that the state must look after the health of the people at large. The Supreme Court interpreted the 'Right to Health' of Article 21 as a part of Right to Life (Ambedkar, 2018). But in reality the court played an important role by establishing positive obligations to improve and maintain public health. No steps were taken to look after the constitutional commitment about the wellbeing and quality of life of the manual scavengers. For the development of human resources, three inputs are considered essential: Nutrition, health and education (Deepu, 2016). 
During the current time of COVID-19, the risk of life for the sewer cleaners is higher than before. The deadly Coronavirus is taking the lives of thousands of people, on the other hand, the workers continue doing their jobs as there is no replacement for them. They enter into deathbeds only to earn a living but in return take along with them hazardous health problems to the home. India has a mixed healthcare system with both public and private sectors playing vital roles. The current capacity of hospital accommodation is saturated with the influx of COVID-19 patients, leaving no space and healthcare facilities for routine care. The health hazards faced by the manual scavengers call for an emergency in healthcare centres but because of the COVID-19 pandemic, their chances of getting admitted and treated seem negligible making them more vulnerable yet prone to death as the cost related to COVID-19 treatment is much higher than their daily wages (Nair, 2020).

\section{CONCLUSION}

Manual Scavenging in India is an intrinsic issue tying the thread of life and death of millions . The practitioners are stuck in a loop of endless humiliation and poverty.Due to this reason, any attempt to address it and to eradicate it has not met with success . Moreover, the practice of manual scavenging is caste-based and dehumanizing. No one should be forced to commit to a work that devalues their status and human rights especially in a country like India, who is a signatory to Human Rights Convention No. 111 of the United Nations. After being initially outlawed in the year 1993, it is still present and persistent.

The inability to implement laws and the prevalence of contract-based employment without permanent employment or decent wages has led to the amplification of their marginalization in India. Manual scavengers clean manholes with only simple manual tools and without any protective gear. It has rendered this particular section of the society extremely vulnerable in the times of COVID-19.

The Dalit community that has been historically associated with this occupation is at the forefront during this pandemic. They face the dual challenge of freedom, restoration and rehabilitation - Liberation from the unfeeling occupation to lead a life with nobility 
and recovery in the far reaching terms including social, religious, monetary and political viewpoints and perspectives.

The inability of government programs to mend out solutions lies in its historical ways of dealing with the issues. The governmental policies emphasize on the monetary facet of rehabilitation but do not address the issue of caste oppression and the social conditions that have preserved this practice since centuries. In the past years, multiple states have denied the existence of dry latrines, thereby declining to force the Employment of Manual Scavengers and Construction of Dry Latrines (Prohibition) Act, 1993 practice of manual scavenging, even though there is evidence telling otherwise. Whereas in other states implementation has not been successful because the law is not clear about the responsible areas and there is no mention of penalties if it is not enforced. Thus, the law is vague and deficient. Additionally, absence of a monitoring body at the state level or the national level makes it even more difficult to foresee its execution (Singh \& Unnikrishnan, 2020).

Technologically, there has been an introduction of machines to clean sewers and drains in India but its reach is limited to wider roads. In a country with an endless number of alleys and small lanes, cleaning via manual scavenging is deemed as the only option. There is a need to evolve the whole practice of manual scavenging. What is needed is more mechanization and technical innovation to effectively clean sewers. Additionally, we need to encourage more research and evolution of technology so that effective machinery can reach the smallest of lanes.

Urgently, there is a need for the total abolishment of contract-based employment. This would reveal the statistics of the actual number of manual scavengers, most of whom are not even counted in surveys due to their non-permanent nature of work. All of this should be at the expense of ensuring the security of the workers which includes good pay, protective equipment as well as recognition of their dignity. This also brings out the need for a good drainage system. The responsibility for a good drainage system also lies at the individual level. It is not unknown that a lot of unnecessary objects are flushed down in toilets in general. This needs to stop and it's time people realize their duty towards effective waste management. 
Rehabilitating manual scavengers is a major challenge that requires a deep and comprehensive approach to lay focus on all crucial aspects to aid in securing the future of their next generation. The only way to consolidate their status in the political sense of meaning lies in giving them positive liberty (Kavitha, 2016). The humiliation and ignorance faced by them can only be eradicated if affirmative action encompassing the ideals of freedom and liberty are taken into account by the state. Creating alternative employment opportunities is an important step for reestablishment. Equal opportunities would be offered to the locals through new jobs which will also provide means to assimilate manual scavengers into the larger community and provide social inclusion. An example of this would be providing loans by utilizing loaning schemes such as Special Component Plan, MGNREG Act (Mahatma Gandhi National Rural Employment Guarantee Act), pension schemes, scholarships, rural housing schemes among others.

As a community, many people are still unaware of the seriousness of the practice of manual scavenging and its brutality on workers. Therefore there is a need to educate people on health and hygiene affairs as well as sanitation. The legal consequences of engaging in manual scavenging practices of existence of dry toilets must be known and published such that people are well aware of the legal sanctions. There is a need to conduct awareness campaigns that aim at addressing the perils of this practice and essentially provide viable and alternative modes for the employment of the same. Sanitation workers need to be aware of what rights they have and the laws that safeguard them from employer abuse. The role of the media is crucial as it can make people aware at the ground level and act as a bridge between the workers and the government for complete reformation.

The reallocation of the funds along with strategic planning to give the funds to the community should be done by the people in charge. The assets delivered by the Total Sanitation Campaign should be placed in good use. Earlier, the assets were distributed however were not used (Rinkesh, 2018).

Above all, the government needs to enforce and implement the law that prohibits scavenging. In India, the law was sanctioned in 1993 and changes were made in 2013. 
Be that as it may, legislative institutions are hesitant to act and go incredible lengths in preventing the existence of manual scavengers. Investing in effective and appropriate machinery to clean ditches and septic tanks can be of massive help. These can be imported if not available locally.

Lack of education resulting in a lack of awareness is one of the key reasons for the manual scavenging crisis. Therefore, ways and means to educate the manual scavengers and their children should and must form the pinnacle of the ideology of the government and civil society. Proper education can result in their proper emancipation.

The current pattern of inter-group inequality matches the economic scheme of the caste system. Fixed economic rights defined by caste with unbending boundaries against change prompts to the forced exclusion of manual scavengers. Jobs viewed as socially degrading, nearly by definition, reduce the social status of those who hold them scavenging being the classic example. Ambedkar (1936) called attention to the jobs to which untouchables are restricted engender aversion, ill will, and the desire to evade (Thorat and Newman, 2007). Manual scavengers are cramped in the economic sense and repressed as citizens, as they are - in practice, even if not in principle - denied civil, political, and socio-economic rights. Therefore, not surprisingly, we find at the bottom of the caste system, manual scavengers mired in undying poverty. Moreover, on the grounds of restriction that it is based on, the caste system fosters inter-group conflict that is socially harmful and diverts human resources to destructive ends (Ibid).

The catastrophe of manual scavenging needs to end. Entrapped in desperation and helplessness, the time has come for the state and the civil society to hold up the ideals of Article 38 of the Indian Constitution, to promote social, economic, and political justice for the welfare and development of the manual scavengers. Manual scavenging is not just a national issue but a national emergency.

\section{CONFLICT OF INTEREST}

There is no conflict of interest

\section{SOURCE OF FUNDING}

Nil 


\section{ACKNOWLEDGEMENT}

Firstly, we would express our heartfelt gratitude to the Centre for Research, Maitreyi College for providing us with the opportunity of conducting research under the summer internship program. Secondly, we would like to thank the Professors of the Department of Sociology, Maitreyi College, the University of Delhi for imparting us with theoretical knowledge about Sociological Imagination and for helping us understand social phenomena.

\section{REFERENCES}

Ambedkar, B.R. (2014). Annihilation of Caste: The annotated critical edition. Navayana Publication Pvt.

Ambedkar, B.R.(2018).The Constitution of India. Educreation Publishing; Bare Act edition.

Anand, S., \& Vellanki, V. (2015). Bhimayana: Caste, Ambedkar, Art, and Pedagogy. Contemporary Education Dialogue,12(2), 271-277. Retrieved from https://journals.sagepub.com/doi/abs/10.1177/0973184915581932

Bhosle, P. (2020). Now, an app to spread Coronavirus awareness among the city's manual scavengers. Mid-Day. Retrieved from https://www.midday.com/articles/coronavirus-outbreak-digital-literacy-for-manual-scavengersto-create-awareness-on-covid-19/22803223

Couillard, M. A. (1990). James C. SCOTT: Domination and the Arts of Resistance. Hidden Transcript, New Haven, Yale University Press, 1990, xviii+ 251 pages, bibliogr., index. Anthropologie et Sociétés, 14(3), 147-149. Retrieved from https://www.erudit.org/en/journals/as/1990-v14-n3-as786/015152ar.pdf

Dash, D.K. (2019). Not a single conviction in deaths of sewer cleaner: Govt. The Times of India. Retrieved from https://m.timesofindia.com/india/not-a-singleconviction-in-deaths-of-\%20sewer-cleanersgovt/amp_articleshow/70746688.cms 
Deepu, P. (2016). Right to Health as a Constitutional Mandate in India. JSS journal for Legal Studies and Research, IV(1). Retrieved from http://jsslawcollege.in/wpcontent/uploads/2013/12/RIGHT-TO-HEALTH-AS-A-CONSTITUTIONALMANDATE-IN-INDIA.pdf

Desai, D. (2020). 282 deaths in last 4 years: How Swachh Bharat Mission failed India's manual scavengers. The Print. Retrieved from https://theprint.in/india/282deaths-in-last-4-years-how-swachh-bharat-mission-failed-indias-manualscavengers/354116/

Dey, A. (2017). Can Delhi really implement its plan to fully mechanize drain and sewer cleaning. Retrieved from https://amp.scroll.in/article/848892/can-\%20delhireally-implement-its-plan-to-fully-mechanise-drain-and-sewer-cleaning

DHNS (2019). Manual Scavenging Shame Continues. Deccan Herald. Retrieved from https://www.deccanherald.com/opinion/first-edit/manual-scavenging-shame720905.html

EFE (2018). India's sewer cleaners, dangerous work for little money. Retrieved from https://www.efe.com/efe/english/world/india-s-sewer-cleaners-dangerouswork-\%20for-little-money/50000262-3788963

Gandhi, D. (2018). The First Robots Clean India's sewers: 25 years after Manual scavenging was out lawed Retrieved from https://www.thehindu.com/society /the-first-robots-clean-indias-sewers-25-years-after-manual-scavenging-wasoutlawed/article24841833.ece

Garg, N. (2019). Understanding India's Sanitation Workers to Better Solve Their Problems. The Wire. Retrieved from https://m.thewire.in/article/labour/ understanding-indias-sanitation-\%20workers-to-better-solve-their-problems

Gautam, C. (2020). Sanitation workers amidst Covid -19: Indispensable yet disregarded. Retrieved from http://rsrr.in/2020/09/01/sanitation-workersamidst-covid/ 
Gnana, S.R. (2018). The Caste System, Dalitization and its implications in Contemporary India. International Journal of Sociology and Anthropology, 10(7), 65-71.

Hindustan Times. (2003). Origin of Caste System in India. Retrieved from

https://www.hindustantimes.com/india/origin-of-caste-system-in-india/storyYrn59d6kPIOVdmhr6qr4LK.html

Kannan, S. (2019). India's Manual Scavengers: Media must be used more effectively to spread awareness; popular faces should use influence for social causes. First Post. Retrieved from https://www.firstpost.com/india/indias-manualscavengers-media-must-be-used-more-effectively-to-spread-awarenesspopular-faces-should-use-influence-for-social-cause-6820721.html

Kavitha , K. (2016). Positive Liberty is the Answer in India. retrieved from http://southasiajournal.net/positive-liberty-is-the-answer-in-india/

Kushner, J. (2020). The Role of Social Media during Pandemic. Khoros. Retrieved from https://khoros.com/blog/social-medias-role-during-covid-19

Mills, C. W. (2000). The Sociological Imagination. Oxford University Press

Nair, S. (2018). One manual scavenging death every five days: Official data. The Indian Express. Retrieved from https://indianexpress.com/article/india /officialdata-shows-one-manual-scavenging-death-every-five-days-5361531/

Nair, S. (2020). COVID-19 treatment: From affordable public hospitals to expensive private care, what it costs to treat a patient in India. First Post. Retrieved from https://www.firstpost.com/health/covid-19-treatment-from-affordable-publichospitals-to-expensive-private-care-what-it-costs-to-treat-a-patient-in-india8623421.html

Naseem, A. (2020). Jalaun's Manual Scavengers- Fighting for Right to Life with Dignity. Retrieved from https://www.oxfamindia.org/blog/jalauns-manualscavengers-fighting-right-life-dignity 
Parpola, M. (2015). Introductory Considerations about Purity, Pollution, and Ritual. Studia Orientalia Electronica, 91, 57-69. Retrieved from https://journal.fi/store/article/view/51289

Questions : Lok Sabha. (2020). Retrieved from http://164.100.47.194/Loksabha/ Questions/QResult15.aspx?qref=71159\&lsno=16

Rashtriya Garima Abhiyaan (2013). Retrieved from http://www.mfcindia.org/ main/bgpapers/bgpapers2013/am/bgpap2013h.pdf

Rinkesh. (2018). What is manual scavenging? Retrieved from https://www.conserveenergy-future.com/causes-effects-solutions-manual-scavenging.php

Mishra, D. (2019). RTI Reveals Threefold Rise in Number of Manual Scavengers Despite Ban. (2020). The Wire. Retrieved from https://thewire.in/rights/rtireveals-threefold-rise-in-number-of-manual-scavengers-despite-ban

Krushna, S.G. \& Afaq, A. (2018). News Media Coverage on Human Rights Issues: Comparative Analysis of the Times of India and the Hindu. Journal of Knowledge \& Communication Management, 8(2), 149-165. http://dx.doi.org/10.5958/2277-7946.2018.00012.8

Chaturvedi S. \& Preet, P. (2019). Manual scavenging: outlawed, yet persisting, Völkerrechtsblog. doi: 10.17176/20190913-112553. Retrieved from https://voelkerrechtsblog.org/articles/manual-scavenging-outlawed-yet-persisting/

Singh \& Manish (2017) Centre of Policy Research: Manual Cleaning of Sewers and septic tanks. Retrieved from https://www.cprindia.org/research/reports/ $\underline{\text { manual-cleaning-sewers-and-septic-tanks }}$

Singh, A. \& Unnikrishnan, A. (2020). Why manual scavengers in India haven't got their rights despite laws, judiciary intervention. Retrieved from https://theprint.in/opinion/why-manual-scavengers-in-india-havent-got-theirrights-despite-laws-judiciary-intervention/371140/ 
Sripathi, A. (2017). How Public Apathy Continues to Keep Manual Scavengers Invisible and in theMargins. Retrieved from https://thewire.in/rights/kakkoosmanual-scavenging

Thankappan, R. (2019). Firstpost: Despite Dalit political assertion, casteism within a community keeps issues affect despite Dalit political assertion, casteism within a community keeps issues affecting manual scavengers on the sidelines. Retrieved from https://www.firstpost.com/india/despite-dalit-politicalassertion-casteism-within-community-keeps-issues-affecting-manualscavengers-on-the-sidelines-6800271.html

The Gazette of India Report (2013). Ministry of Law and Justice. Retrieved from https://ncsk.nic.in/sites/default/files/manualscaact19913635738516382444610.pdf

The Hindu (2020). Manual scavenging: 17 deaths in four years. Retrieved from https://www.thehindu.com/news/national/karnataka/manual-scavenging-17deaths-in-four-years/article30696512.ece/amp/

Thomas, L. (2020). India: the struggle of Coimbatore sanitation workers. Retrieved from https://www.marxist.com/india-the-struggle-of-coimbatore-sanitationworkers.htm

Thorat, A. (2010). Ethnicity, Caste \& Religion: Implications for Poverty and Outcomes. Economic and Political Weekly, 45(51), 47-53. Retrieved from https://www.jstor.org/stable/25764242

Thorat, S. (2017). Graded Caste Inequality and Poverty Recent Evidence on Role of Economic Discrimination. Retrieved from https://blogs.lse.ac.uk/inequality andpoverty/files/2017/12/Graded-Caste-Inequality-and-Poverty.pdf

Thorat, S. \& Attewell, P. (2007). The Legacy of Social Exclusion: A Correspondence Study of Job Discrimination in India. Economic and Political Weekly, 42 (41), 4141- 4145. Retrieved from https://www.jstor.org/stable/40276548 
Thorat, S. \& Newman, K.S. (2007). Caste \& Economic Distribution: Causes, Consequences and Remedies. Economic and Political Weekly, 42 (41), 41214124. Retrieved from https://www.jstor.org/stable/40276545

Torgalkar, V. (2020). Sanitation Workers on the Frontlines of the Pandemic Are Overlooked, Unprotected. Retrieved from https://theswaddle.com/codi19spreads-india-sanitation-workers-unprotected/

Youth Ki Awaaz. (2017). By the Age of 10, I Was a Manual Scavenger. Retrieved from https://www.youthkiawaaz.com/2017/03/lalibai-story-of-manual-scavenger/

How to cite this article: Chugh, A., Bisht, A., Sarma, N., Koushik, S., Harsana, P. \& Khan, S. (2020). Living on the margins: An interpretative study of Sanitation Workers amidst COVID-19. Vantage: Journal of Thematic Analysis, 1(2): 127-153.

DOI: https://doi.org/10.52253/vjta.2020.v01i02.09

(C) 2020 Vantage: Journal of Thematic Analysis

This work is licensed under a Creative Commons Attribution-ShareAlike 4.0 International License which permits use, distribution and reproduction in any medium, provided the original work is cited and new creations are licensed under identical terms. 